\title{
ANTIBODY RESPONSE TO INFECTIONS WITH TYPE II AND THE RELATED TYPE V PNEUMOCOCCUS ${ }^{1}$
}

\author{
By MAXWELL FINLAND AND ALEXANDER W. WINKLER \\ (From the Thorndike Memorial Laboratory, Second and Fourth Medical Services \\ (Harvard) and the Department of Medicine, Harvard Medical School, Boston)
}

(Received for publication September 19, 1933)

In the preceding communication were reported the results of immunological studies in a group of patients with infections associated with Types III and VIII pneumococci (1). In this paper will be presented similar studies in a group of patients with infections associated with the Types II and $\mathrm{V}$ pneumococci. The latter are the most frequent and most important of the pneumococci immunologically related to Type II (2) and correspond to the Group II $a$ of Avery (3). The materials and the methods were identical with those used in the preceding study.

\section{Agglutination of strains of Types II and $V$ pneumococci in antipneumococcus horse sera of these types}

Tests for cross-agglutination were carried out with 10 Type II and 12 Type V strains. One Type V and 3 Type II antisera from different laboratories were available. The Type $\mathrm{V}$ serum agglutinated one-half of the homologous strains in dilutions up to $1: 80$ and the rest up to $1: 160$ or $1: 320$. This serum failed to agglutinate 4 Type II strains and agglutinated 6 others in dilutions of $1: 10$ or $1: 20$. The Type II sera varied slightly in the titer to which they agglutinated homologous strains; one agglutinated up to $1: 40$, the second to $1: 80$ and the third to $1: 160$. The first failed to agglutinate 8 Type V strains and agglutinated 4 strains in $1: 2$ or $1: 4$ dilutions only, the second agglutinated 8 strains in $1: 4$ dilutions, and 4 others in 1:10 dilution and the third did not agglutinate 6 Type $\mathrm{V}$ strains and agglutinated the rest in $1: 4$ dilutions only.

Microscopic agglutination tests with each strain in 1:10 dilutions of each antisera always showed a clear differentiation. The agglutination with the homologous type antisera was marked. In the related type antiserum agglutination was either absent, or the clumps were small, without much serum surrounding them, and many free unagglutinated organisms were seen.

Thus, cross agglutinations were observed with each of the antisera used, but these were chiefly in the macroscopic tests. There was no defi-

1 This investigation was aided, in part, by a grant given in honor of Francis Weld Peabody by the Ella Sachs Plotz Foundation. 


\begin{tabular}{|c|c|c|c|c|c|c|c|}
\hline \multicolumn{2}{|l|}{$\mid$} & 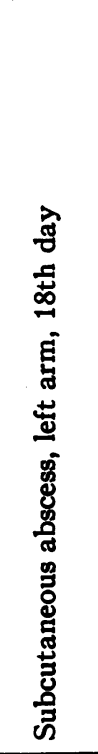 & 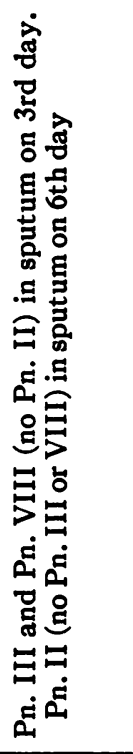 & 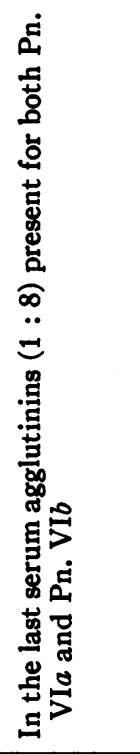 & \multicolumn{3}{|l|}{ 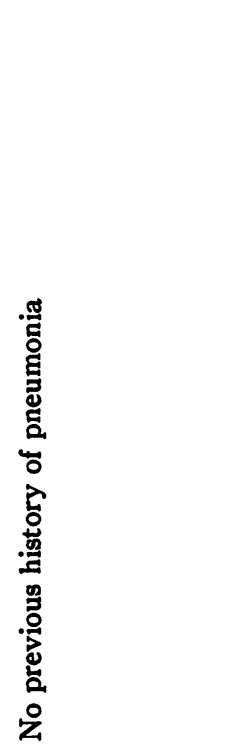 } \\
\hline \multirow{2}{*}{ 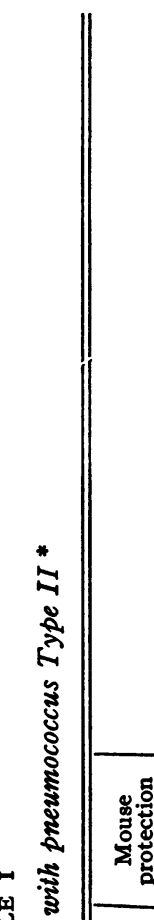 } & 息 & 00 & 0100 & 0000 & పై & 00 & 0 \\
\hline & 莤 & 웅 & 号 1 ర్త & 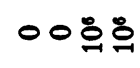 & 응응 & 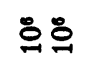 & 을 \\
\hline . & $\dot{a}>$ & 00 & 0000 & 0000 & 000 & 00 & 0 \\
\hline 然.] & $\dot{a j}$ & ○ల్లు & $0+\infty 0$ & $00 \infty \underline{1}$ & +뭉으 & $N H$ & $\infty$ \\
\hline ڤ్ & & m శ్ & $\infty$ 으 & ด๑ $\cong \pi$ & $\exists \cong \vec{N}$ & $a m$ & $m$ \\
\hline : & मึ & in & 욱 & $a$ & $N$ & 0 & in \\
\hline$\underset{\leftrightarrow}{\stackrel{g}{\mathrm{~d}}}$ & ¿ँّ & 量 & 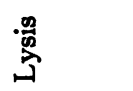 & U. & 兽 & 尊 & 蠻 \\
\hline Џ્さ & Å & $N+$ & $n \times \infty$ & moa & 0 & in & $m$ \\
\hline 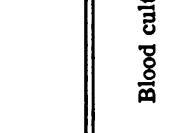 & 䓛 & 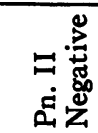 & 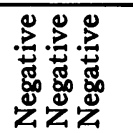 & 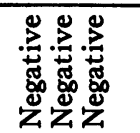 & $\begin{array}{l}\boxminus \\
\dot{a}\end{array}$ & 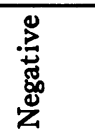 & 总 \\
\hline & 选 & క్ & 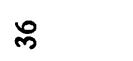 & $\infty$ & F & $F$ & $=$ \\
\hline & & $\stackrel{\dot{\varphi}}{\stackrel{-}{ }}$ & $\begin{array}{l}\dot{\theta} \\
\dot{0} \\
\dot{\sim}\end{array}$ & $\stackrel{\dot{\oplus}}{\oplus}$ & $\begin{array}{l}\dot{0} \\
\dot{\Sigma}\end{array}$ & $\dot{v}$ & $\underset{\sim}{ن}$ \\
\hline లో & & $\mathfrak{N}$ & 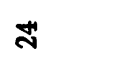 & 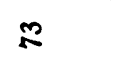 & 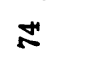 & $\mathfrak{2}$ & 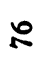 \\
\hline
\end{tabular}



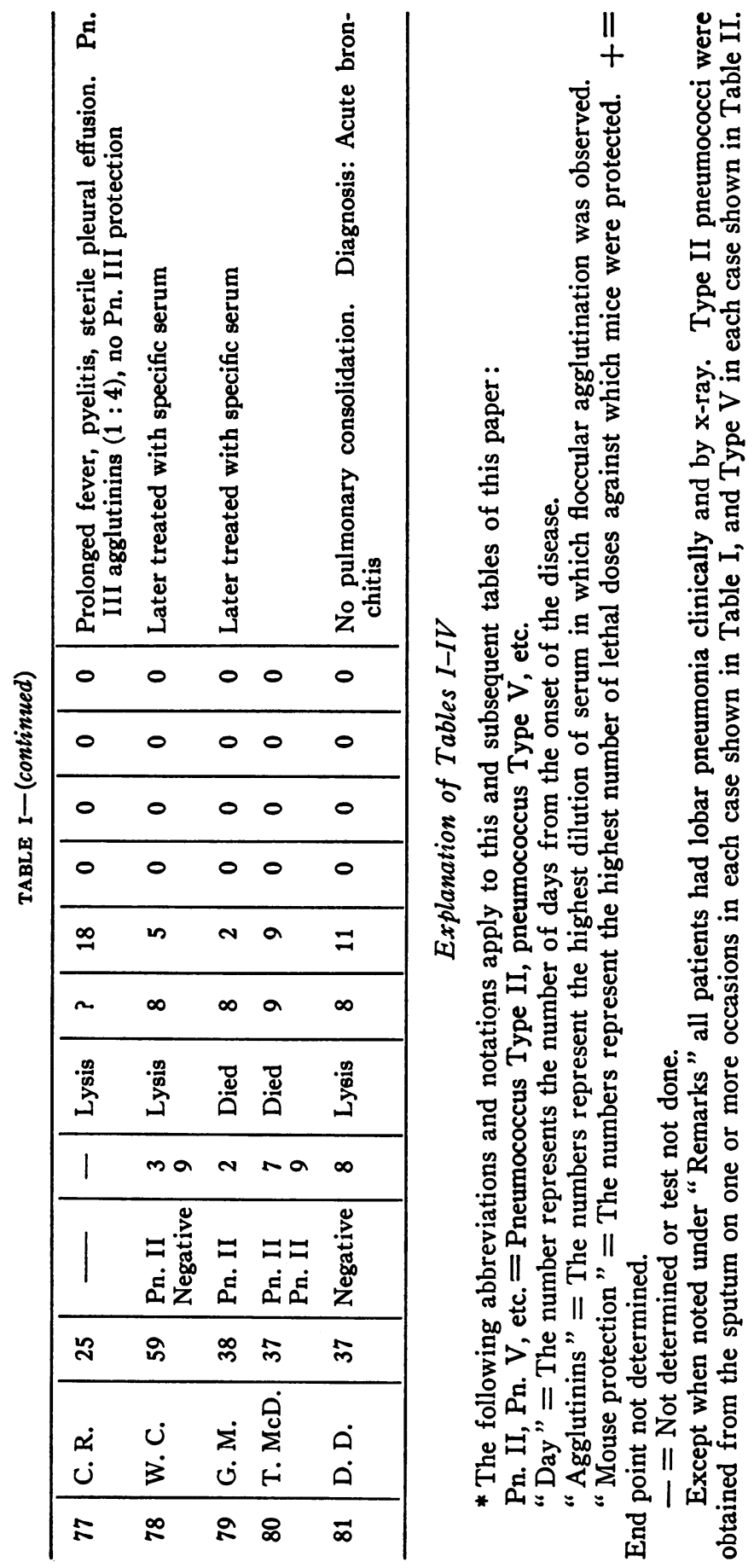
nite relationship between the cross-agglutination and the titer of agglutinins for the homologous type strains.

\section{Agglutinins and protective antibodies in patients with infections associated with Type II and Type $V$ pneumococci}

The results of tests for agglutinins and mouse-protective antibodies for Types I and II pneumococci in the sera of 11 patients with Type II pneumococcus infections are shown in Table I and those in 25 patients with Type V pneumococci appear in Table II. None of these patients received pneumococcic antibody or antigenic substances before these sera were obtained. Each serum was tested for agglutinins with 4 Type V strains and, in addition, with strains of about 15 different types of pneumococci. The data in Tables I and II are summarized in Table III.

The results in each of these 2 groups of patients were remarkably similar. Almost all of the patients with pneumonia who recovered, showed protective antibodies against 100 or more lethal doses of the homologous type pneumococcus in their serum about the time of recovery or later. Two patients who were studied only during the acute disease and did not have antibodies at that time were later given specific antiserum and the studies discontinued. The findings of agglutinins for the homologous type paralleled, in general, the protective antibodies. The titer of Type V agglutinins was practically the same in any given serum with each of the different antigens used. Occasionally protective antibodies were demonstrated before the appearance of agglutinins or when the latter could not be demonstrated at any time.

The patients with infections other than typical lobar pneumonia are of special interest. Antibodies for the homologous organism were demonstrated in the serum of one patient with bronchopneumonia and another with a common cold associated with the finding of Type $\mathrm{V}$ pneumococci in the sputum. In a third patient with acute bronchitis and with Type II pneumococci in the sputum, no antibodies could be demonstrated.

Cross-immunity, as judged by the mouse-protection tests, was observed, but infrequently. In no instance, however, was cross-agglutination observed; nor was cross-protection demonstrated in the absence of the homologous type antibody.

All of the fatal cases failed to show antibodies for either type by either test.

\section{Mixed infections}

There were 3 patients (Cases 24, 90 and 21) from whom other types of pneumococci were recovered in addition to the Type II or V organism. Each of these patients had antibodies for the latter organisms only. From two other patients (Cases 14 and 27, see Table I in previous communication (1)) only Type III pneumococci were obtained, but the serum showed 


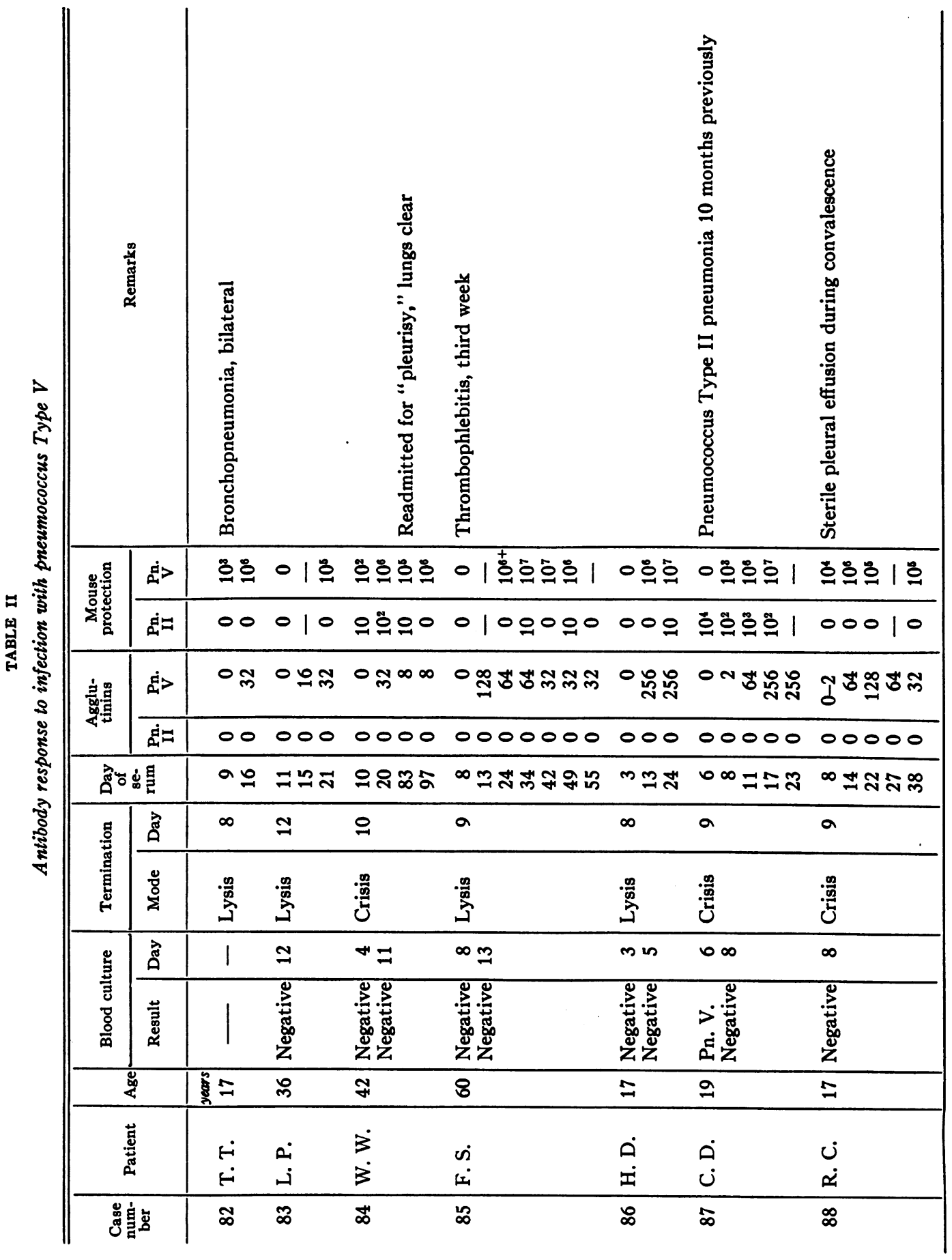




\begin{tabular}{|c|c|c|c|c|c|c|c|c|}
\hline \multicolumn{2}{|c|}{ 咅 } & & 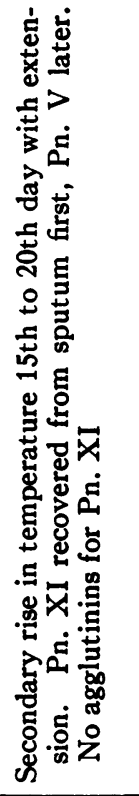 & & & & & 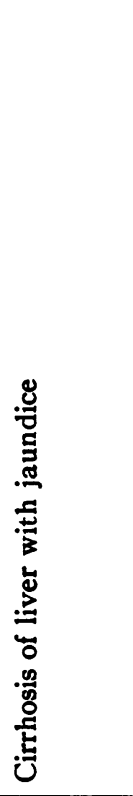 \\
\hline \multirow{2}{*}{ 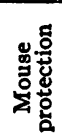 } & $\dot{\text { i }}$ & 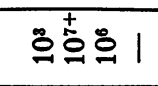 & ○ ర్తం \%ั & $\circ \stackrel{0}{0}$ & 응요호 1 & 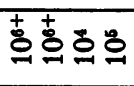 & 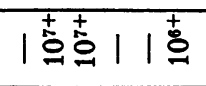 & 이 1 훙 \\
\hline & $\dot{\dot{x}}=$ & 0001 & 0000 & 00 & 0001 & 0000 & 100110 & 0110 \\
\hline \multirow{2}{*}{ 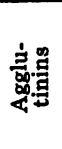 } & $\dot{\square}$ & N & $0 \operatorname{IIT}^{n}$ & 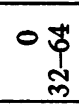 & 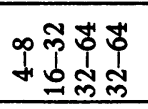 & †ై & 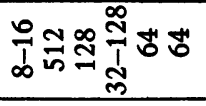 & 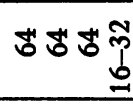 \\
\hline & 近 & 0000 & 0000 & 00 & ONNN & 0000 & 000000 & 0000 \\
\hline \multicolumn{2}{|c|}{ 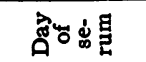 } & $0=\infty \Re$ & $\forall=\bar{m}$ & $\infty \stackrel{\infty}{-}$ & ดำส & 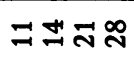 & 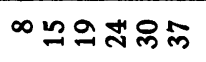 & 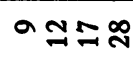 \\
\hline \multirow{2}{*}{ 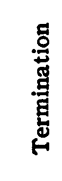 } & คี & $\infty$ & $n \Xi \bar{N}$ & $\infty$ & $\Rightarrow$ & $a$ & $\infty$ & $\infty$ \\
\hline & $\sum_{\Sigma}^{\circ}$ & $\frac{\frac{n}{2}}{2}$ & 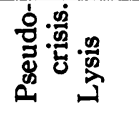 & $\frac{0}{2}$ & $\frac{\frac{2}{2}}{2}$ & $\stackrel{\frac{n}{5}}{3}$ & 量 & $\frac{\frac{2}{2}}{2}$ \\
\hline \multirow{2}{*}{ 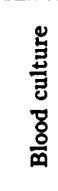 } & คิ & no요 & 1 & - & 1 & $a \simeq$ & $\infty$ & 1 \\
\hline & 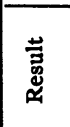 & 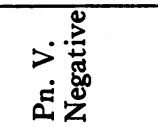 & 1 & $\begin{array}{l}\dot{s} \\
\dot{a}\end{array}$ & | & 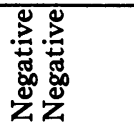 & 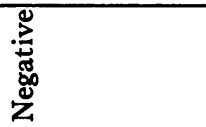 & 1 \\
\hline \multicolumn{2}{|c|}{ 㟧 } & ไู่ & 苞 & $\overrightarrow{0}$ & 号 & $\overrightarrow{0}$ & 암 & กี \\
\hline \multicolumn{2}{|c|}{ 苞 } & $\dot{3}$ & $\dot{z}$ & $\begin{array}{l}\dot{v} \\
\dot{x} \\
\dot{\sim}\end{array}$ & $\begin{array}{l}\stackrel{0}{\pi} \\
\stackrel{3}{~}\end{array}$ & $\dot{0}$ & $\stackrel{\dot{m}}{\check{\infty}}$ & $\begin{array}{l}\stackrel{\dot{J}}{\Sigma} \\
\stackrel{\dot{m}}{ }\end{array}$ \\
\hline \multicolumn{2}{|c|}{ 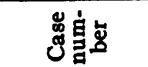 } & ळి & \& & $\bar{a}$ & $\approx$ & 2 & \$゙ & $\check{\alpha}$ \\
\hline
\end{tabular}




\begin{tabular}{|c|c|c|c|c|c|c|c|c|c|c|}
\hline \multicolumn{2}{|c|}{ 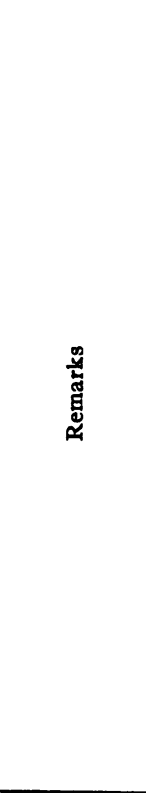 } & \multicolumn{3}{|c|}{ 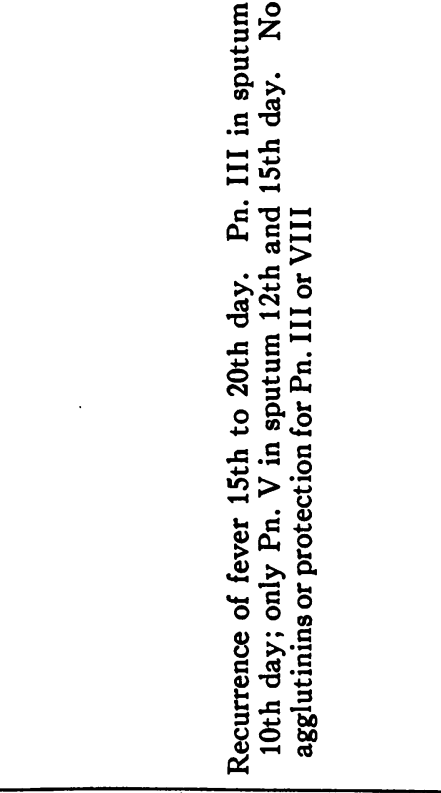 } & 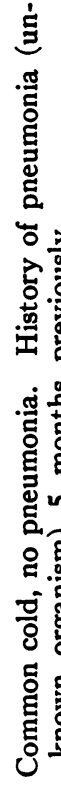 & 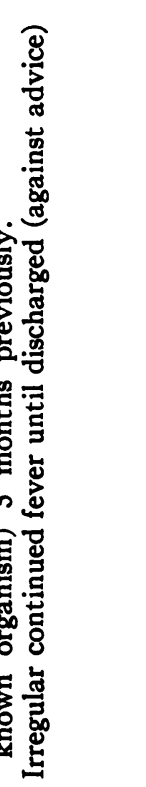 & & & & \\
\hline \multirow{2}{*}{ 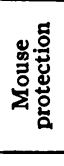 } & $\stackrel{\text { ip }}{ }$ & 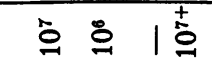 & 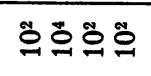 & 으으 & & 1101 & 0 & 0 & 오 & \\
\hline & $\dot{a}=$ & 0010 & 0000 & ㅇㅇ & 0 & 1111 & 0 & 0 & 0 & \\
\hline \multirow{2}{*}{ 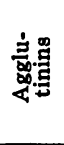 } & $\dot{\text { p }}$ & 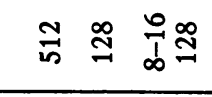 & 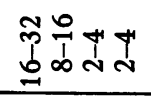 & 00 & 0 & 0001 & 0 & 0 & 0 & \\
\hline & 혀 & 0000 & 0000 & 00 & 0 & 0001 & 0 & 0 & 0 & 0 \\
\hline \multicolumn{2}{|c|}{ 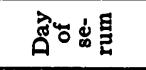 } & 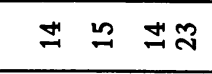 & 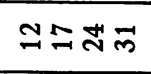 & $\infty \sim$ & & $+\infty \pm 1$ & & 0 & $m$ & \\
\hline \multirow{2}{*}{ 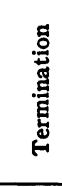 } & $\overrightarrow{\nexists ~}$ & $a a=$ & $\Rightarrow$ 우 & $\infty$ & + & $\sim$ & $\simeq$ & $\infty$ & + & \\
\hline & 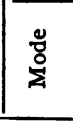 & 足量 & 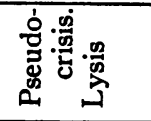 & : & 易 & 量 & تֶّ & 芯 & 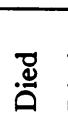 & قِّ \\
\hline \multirow{2}{*}{ 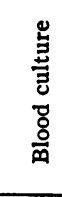 } & ค̆ & $1=\infty a$ & $0 \cong$ & - & 1 & $+\simeq ニ=$ & $a \cong$ & $+\infty$ & $N$ & Nin \\
\hline & 蒙 & 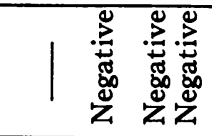 & 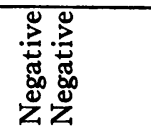 & 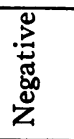 & 1 & 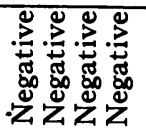 & $\begin{array}{l}\dot{p} \\
\dot{a} \dot{0}\end{array}$ & $\begin{array}{l}\dot{>} \\
\dot{\dot{a}} \dot{0}\end{array}$ & $\dot{s}$ & ن \\
\hline \multicolumn{2}{|c|}{ 岁 } & 岁 & 阊 & స్ల & ల్ల & $\vec{\sim}$ & & ले & 品 & 아 \\
\hline \multicolumn{2}{|c|}{ 崂 } & $\begin{array}{lll}\dot{N} & \dot{\Sigma} & \dot{U} \\
\dot{\mathbf{I}} & \dot{<} & 0\end{array}$ & $\dot{ن}$ & $\dot{\Sigma}$ & $\begin{array}{l}\dot{4} \\
\dot{4}\end{array}$ & $\stackrel{\dot{I}}{\dot{\sim}}$ & $\begin{array}{l}\dot{\sim} \\
\dot{\sim}\end{array}$ & $\dot{4}$ & $\begin{array}{l}ن \\
ن\end{array}$ & \\
\hline \multicolumn{2}{|c|}{ 总完寈 } & ஃ ล ஃ & $\bar{\sim}$ & à & 임 & 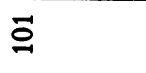 & ऽั & $\dddot{O}$ & Ð艹 & \\
\hline
\end{tabular}


TABLE III

Summary of Tables $I$ and II

Immunity resulting from infections associated with Type II and Type $V$ pneumococci*

\begin{tabular}{l|c|c|c|c|c|c}
\hline \hline & $\begin{array}{c}\text { Infecting } \\
\text { type }\end{array}$ & $\begin{array}{c}\text { Number } \\
\text { patients } \\
\text { tested }\end{array}$ & \multicolumn{2}{|c|}{ Agglutinins present } & \multicolumn{2}{|c|}{ Mouse protection presentt } \\
\cline { 5 - 7 } & II & Pn. V & Pn. II & Pn. V \\
\hline Pneumonias recovered & II & $8 \dagger$ & 6 & 0 & 6 & 1 \\
& V & 20 & 0 & 18 & 2 & 20 \\
Pneumonias fatal & II & 2 & 0 & 0 & 0 & 0 \\
& V & 4 & 0 & 0 & 0 & 0 \\
Acute respiratory infec- & II & 1 & 0 & 0 & 0 & 0 \\
tion (No pneumonia) & V & 1 & 0 & 0 & 0 & 1 \\
\hline
\end{tabular}

* In every instance in which antibodies for the heterologous type were demonstrated, they were also demonstrated for the homologous type.

$\uparrow$ Two cases without antibodies were not studied after recovery.

$¥$ For 100 or more lethal doses.

Type $\mathrm{V}$ antibodies and none for the homologous type. Conversely, one patient (Case 77) with only Type II pneumococci, had antibodies demonstrable for Type III only. Finally, the serum of 1 patient (Case 73) was found to cross-agglutinate with strains of Type VI pneumococci (probably Group II $b$ of Avery $(2,3))$.

\section{Effect of absorption with Types II and $V$ pneumococci on the antibodies for these types}

A number of sera with antibodies for Type II or Type $\mathrm{V}$ pneumococci or both were absorbed with these 2 types of pneumococci and, in some instances, also with Type I organisms. The effect of this absorption on the agglutinins and protective antibodies was studied. The results were quite uniform; they appear in Table IV. The homologous type antibodies were absorbed by that type only and not by the related or unrelated type. The cross-protective antibodies were absorbed by both the homologous and the related type.

\section{DISCUSSION}

The cross-agglutination of strains of Types II and V pneumococci in horse antisera prepared with these types is of practical significance. Therapeutic sera of high potency against Type II have comparatively little protective power against Type V strains (2) and are of no value in treating pneumonia caused by the latter. Inasmuch as large amounts of concentrated Type II antiserum are necessary for the effective treatment of pneumonia due to this type (4), it is important, in determining the pneumo- 


\begin{tabular}{|c|c|c|c|c|}
\hline \multirow{3}{*}{ 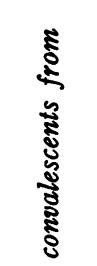 } & \multirow{4}{*}{ 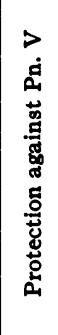 } & \multirow{3}{*}{ 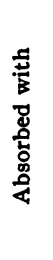 } & $\dot{g}$ & $|\Xi 11| 1|1| 0$ \\
\hline & & & $\begin{array}{l}\vec{s} \\
\dot{a}\end{array}$ & 1010000000 \\
\hline & & & $\begin{array}{l}\Xi \\
\dot{a}\end{array}$ & 1 으 1응응ㅇㅇㅇㅇ \\
\hline $\begin{array}{l}\overrightarrow{0} \\
\mathbf{E}\end{array}$ & & \multicolumn{2}{|c|}{ 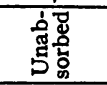 } & 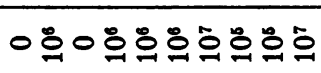 \\
\hline 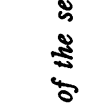 & \multirow{4}{*}{ 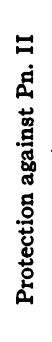 } & \multirow{3}{*}{ 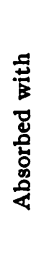 } & $\vec{q}$ & $\approx-1|1| 1|1|$ \\
\hline 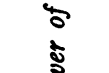 & & & $\vec{r}$ & ڤొ \\
\hline & & & I & $00-1111001$ \\
\hline & & \multicolumn{2}{|c|}{ 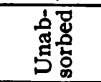 } & 50000008\%0 \\
\hline \multirow{5}{*}{\multicolumn{2}{|c|}{ 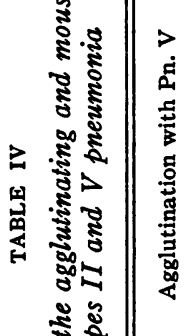 }} & \multirow{4}{*}{ 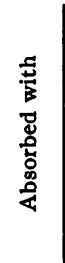 } & - & \\
\hline & & & $\dot{\dot{q}}$ & 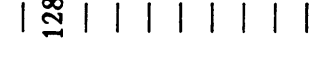 \\
\hline & & & $\vec{a}$ & $10100001 \mid 1$ \\
\hline & & & $\vec{z}$ & 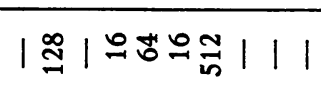 \\
\hline & & \multicolumn{2}{|c|}{ 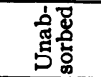 } & 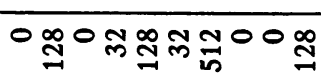 \\
\hline \multirow{4}{*}{\multicolumn{2}{|c|}{ 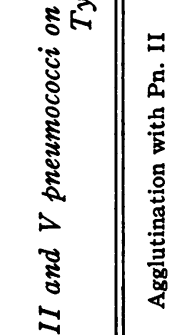 }} & \multirow{3}{*}{ 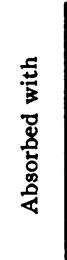 } & $\dot{m}$ & స్ల1 11111111 \\
\hline & & & i & 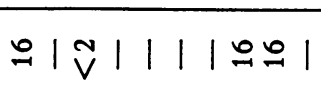 \\
\hline & & & $\ddot{g}$ & 0101111001 \\
\hline & & \multicolumn{2}{|c|}{ 䢔 } & స్లం \\
\hline 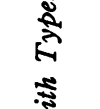 & & \multicolumn{2}{|c|}{ 总 } & 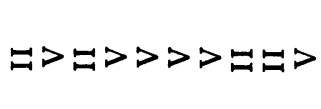 \\
\hline . & & \multicolumn{2}{|c|}{ 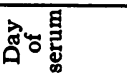 } & 유 $\approx$ 음ำ \\
\hline 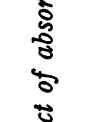 & & \multicolumn{2}{|l|}{ 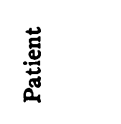 } & 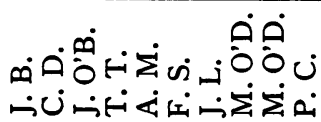 \\
\hline 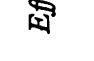 & & \multicolumn{2}{|c|}{ 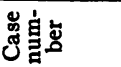 } & 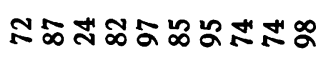 \\
\hline
\end{tabular}


coccus type, to exercise care to exclude Type $\mathrm{V}$ cases from among those selected for treatment with Type II antisera. This may be done by further agglutinating in Type $\mathrm{V}$ antiserum all strains reactive with Type II.

It is interesting to compare the immune response to infections with Types III and VIII pneumococci (1) with those here observed in Types II and V cases. Homologous type-specific antibodies were more constant and of higher grade with the latter types. With the former, crossimmunity was frequent and of high grade, often associated with higher titers of antibody for the related than for the homologous type and, at times, present in the absence of antibodies for the infecting type. With the latter, cross-immunity was infrequent, of low grade so that it could not be demonstrated by the agglutination reaction, and was always associated with the finding of a high titer of antibodies for the homologous type.

The cases mentioned under the heading of "mixed infections" also present an interesting contrast with the corresponding cases in the Type III group (1). The immunological reactions in the latter suggested that the finding of Type III was incidental in most instances and the other organisms were usually etiologically related to the disease. In the present cases the data suggest an opposite conclusion, namely, that in most instances the other organism was incidental and the Type II or V was the important invader. These findings are not difficult to appreciate in view of the frequency with which Type III organisms are found in the normal respiratory passages, and the rarity with which Types II and V organisms occur under similar conditions (5).

\section{SUMMARY AND CONCLUSIONS}

Cross-agglutinations of Types II and V pneumococci in antipneumococcus horse antisera were observed frequently and, in some instances, in dilutions high enough to cause confusion in routine type determinations. The desirability of agglutinating strains of either of these types in both antisera was indicated, especially in relation to the use of specific antisera in treatment.

Homologous type-specific antibodies were found fairly constantly in patients with Type II or V pneumococcus lobar pneumonia who recovered. Fatal patients with either type failed to develop antibodies. Crossimmunity was observed but it was infrequent and of low grade. Where it occurred, absorption experiments indicated that only the organism recovered from the sputum was antigenically active.

The authors gratefully acknowledge the technical assistance of Miss Louise N. Batt and Miss Mary S. Carroll. 


\section{BIBLIOGRAPHY}

1. Finland, M., and Winkler, A. W., Antibody response to infections with Type III and the related Type VIII pneumococcus. J. Clin. Invest., 1934, 13, 79.

2. Cooper, G., Rosenstein, C., Walter, A., and Peizer, L., The further separation of types among the pneumococci hitherto included in Group IV and the development of therapeutic antisera for these types. J. Exper. Med., $1932,55,531$.

3. Avery, O. T., A further study on the biological classification of pneumococci. J. Exper. Med., 1915, 22, 804.

4. Finland, M., and Sutliff, W. D., The specific serum treatment of pneumococcus Type II pneumonia. J. A. M. A., 1933, 100, 560.

5. (a) Webster, L. T., and Hughes, T. P., The epidemiology of pneumococcus infection. The incidence and spread of pneumococci in the nasal passages and throats of healthy persons. J. Exper. Med., 1931, 53, 535.

(b) Gundel, M., Bakteriologische und epidemiologische Untersuchungen über die Besiedlung der oberen Atmungswege Gesunder mit Pneumokokken. Ztschr. f. Hyg. u. Infektionskr., 1933, 114, 659.

(c) Smillie, W. G., The epidemiology of lobar pneumonia. A study of the prevalence of specific strains of pneumococci in the nasopharynx of immediate family contacts. J. A. M. A., 1933, 101, 1281. 